\title{
Hvorfor Frankrig gik ind i Mali?
}

\section{Ulla Holm}

\section{Frankrig besluttede hurtigt at intervenere i Mali, men har ikke nogen klar exitstrategi. Frankrigs problem vil blive, at svage stater kalder på Kina, når det gælder økonomi, og på Frankrig, når de frygter oprørere}

Den franske præsident, François Hollande, er blevet en højt profileret statsmand på grund af militærinterventionen i Mali. Hr. 'normal' er blevet 'rigtig normal', fordi fransk udenrigspolitisk identitet tilsiger høj cigarføring på den udenrigspolitiske arena. I sin tale til de franske ambassadører i august 2012 erklærede Hollande: "Vore universelle værdier har oplyst verden. De bør led lede vore internationale handlinger. De berettiger os at blive lyttet til. Andre lande håber, at vi spiller en nyttig rolle i verden. Hvis Frankrig er tavs og kuldskær, mister Frankrig anseelse".

Denne udtalelse ligger fuldkommen i tråd med tidligere præsidenters erklæringer om Frankrigs rolle i verden. I den franske udenrigspolitiske selvopfattelser involverer fransk 'mission civilisatrice' udenrigspolitisk aktivisme. Frankrig er ikke sig selv, hvis ikke landet handler ud over de franske grænser. At handle eller ikke at handle er et spørgsmål om udenrigspolitisk liv eller død. Det drejer sig om nationalstatens eksistens. Afdøde præsident Mitterrand erklærede således i 1980'erne kort og fyndigt 'at handle er at eksistere'.

\section{I etikkens navn}

Frankrig som bannerfører af universelle værdier som demokrati og menneskerettigheder er en fast bestanddel af fransk udenrigspolitisk selvopfattelse. Med militærinterventionen i Mali ville Frankrig vise, at når andre stater ikke ville tage affære over for grusomheder mod dele af befolkningen, ja så måtte Frankrig handle i etikkens navn. 
En vigtig legitimering for interventionen var derfor pligten til at beskytte det nordlige Malis befolkning mod den voldelige udgave af sharia.

Hertil kommer, at Frankrig som tidligere kolonisator af vestafrikanske lande stadig betragter sig som udefrakommende 'beskytter' af landene.

En anden faktor, der sikkert har været medvirkende til interventionen, er 'spill-over'-effekten fra interventionen i Libyen, som daværende præsident Sarkozy tog initiativet til. Den socialistiske Hollande vil vise, at han er lige så aktivistisk som den borgerlige Sarkozy.

Der er imidlertid en politisk forskel mellem interventionen i Libyen og i Mali. I Libyen var det Gaddafiregimet, der blev bekæmpet. I Mali er det regimet, der støttes for at undgå nedsmeltning af staten. Frankrig er bekymret for, at Mali vil blive en fejlslagen stat.

Hvis man med fejlslagen stat mener, at store dele af det nationale territorium undslipper statens kontrol og voldsmonopol, så har Mali siden uafhængigheden i 1960 være en fejlslagen stat. I det nordlige Mali har der ofte været tuaregoprør mod regeringen i hovedstaden Bamako. Grænserne mellem Sahel-staterne har altid været porøse og derfor ukontrollerbare i forhold til smuglere og narkohandlere.

Når Hollande, udenrigsminister Fabius, forsvarsminister Le Drian,
FN og EU således erklærer, at formålet med aktionen er at genetablere Malis enhed og territoriale integritet, er der tale om en sandhed med modifikationer. Det handler snarere om etablering af Malis enhed.

\section{Kampen mod terror}

Nødvendigheden af (gen)etablering af den territoriale enhed skyldes angsten for udbredelsen af islamisk terror til hele Sahel-området. Franske statsborgere er blevet kidnappet i Sahel-området i de senere år. Ledere af Al-Qaeda i det Islamiske Maghreb (AQIM) har ofte truet Frankrig med bål og brand. Frankrig selv har været genstand for islamistiske attentatforsøg.

Da den maliske midlertidige præsident Traoré i januar opfordrede Frankrig og Europa til at redde Mali fra islamiske terroristers march mod hovedstaden Bamako, handlede Hollande lynhurtigt. Ifølge Hollande var interventionen en 'krig mod terrorisme'. Ikke siden George W. Bushs tale om 'global krig mod terroren' i forbindelse med 9/11 har en statsleder så tydeligt erklæret krig mod terrorister. Men ifølge Hollande er det terrorister, ikke islamistiske terrorister, der skal udraderes.

$\mathrm{Al}$ tale om islam som trussel er bandlyst i alle Hollandes udtalelser. Hollande undgår at tale om 'civilisationernes sammenstød' for ikke at støde muslimerne i Frankrig.

Hollande fremstiller kampen mod 
terror som en eksistentiel trussel ikke alene mod Mali, men også mod Frankrig og Europa. En sådan trussel legitimerer brugen af ekstraordinære midler - dvs. militærmagt, fordi det handler om befolkningers og staters overlevelse. Det frygtelige terrorangreb i slutningen af januar 2013 mod gasfeltet In Amenas i det sydlige Algeriet, hvor flere europæiske og canadiske borgere blev dræbt, bestyrkede Hollande i, at terroren er en eksistentiel trussel mod Europa.

Flere franske terrorforskere mener imidlertid, at terroristerne i Sahel og Sahara ikke har tilstrækkelig styrke til at slå til i Frankrig og Europa. Det, der kan ske, er, at interventionen kan give terrormiljøerne i Europa blod på tanden, og at udenlandske professionelle terrorister vil slutte sig til Malis terrorister.

Terrortruslen fremstilles som den vigtigste officielle årsag til interventionen. Og den fremstilling er der opbakning til både internt i Frankrig og på internationalt plan. Der har imidlertid været røster fremme på den franske venstrefløj og blandt franske forskere, der mener, at den franske intervention tjener til at beskytte franske økonomiske interesser i Mali. Skønt de økonomiske relationer mellem Mali og Frankrig er forblevet relativt vigtige efter Malis uafhængighed i 1960, er Mali kun nummer 165 af franske økonomiske partnere. Mali eksporterer især bomuld og guld til Frankrig. Men Malis guldminer er først og fremmest på sydafrikanske og britiske hænder. Geologer har påvist, at der i Malis undergrund findes store uranforekomster, som Frankrig selvfølgelig vil være interesseret i pga. sine atomkraftværker.

\section{Udfordret af Kina}

Franske økonomiske interesser i Afrika er udfordret af især kinesisk økonomisk 'invasion'. Kina investerer specielt i infrastruktur, transport, energi og telekommunikation. Kina er ikke 'plettet' af kolonial fortid og stiller ikke krav om overholdelse af menneskerettigheder. Kina har derfor gode diplomatiske forbindelser med regeringerne i Vestafrika.

Frankrig ser ikke med milde øjne på denne økonomiske konkurrent. Der tales oven i købet om fremkomsten af 'Chineafrique' (kinesisk Afrika), som står i modsætning til 'Francafrique' (fransk Afrika). Men det er ikke i Mali, at konkurrencen ytrer sig. Det er i Niger, som er den fjerde største producent af uran i verden. Frankrig har hidtil været den største udvinder af uran i Niger, men Kina arbejder på at få koncession på uranudvinding.

Frankrig er bestemt ikke uinteresseret $\mathrm{i}$ at fastholde sine økonomiske interesser i Vestafrika og i Sahel. Men interventionen i Mali er først og fremmest dikteret af geopolitiske årsager. Bag ved terrortruslen ligger bekymringen for, at ukontrollable 
områder spreder sig i Sahel og dermed hindrer 'normale' diplomatiske stat-til-stat forbindelser. Denne frygt deles af alle de svage Sahel-stater, som derfor har bakket fransk intervention op. Det gælder især Malis naboland Niger, som har været den ivrigste fortaler for fransk militærintervention.

Problemet for Frankrig i Vestafrika vil for fremtiden være, at svage stater vil kalde på Kina, når det handler om økonomiske interesser, og kalde på Frankrig, når staterne frygter at blive destabiliseret af oprørere. Frankrig kan risikere at fortsætte med at spille rollen som 'Afrikas gendarm' snarere end at være den økonomiske magt, som de frankofone afrikanske stater vil samarbejde økonomisk med.

\section{Franske interventioner}

Siden 1960, hvor de fleste franske kolonier i Afrika blev uafhængige, har Frankrig interveneret omkring 50 gange i forsøget på at stabilisere korrupte styrer, der tjener franske $\varnothing$ konomiske og geopolitiske interesser. Disse interventioner er foregået inden for rammerne af bilaterale forsvars- og militæraftaler. Der er dog sket en betydelig reduktion af interventioner siden midten af 1990'erne.

De franske landtroppers tilstedeværelse i 'Francafrique' er også blevet reduceret. Efter 1960 havde Frankrig ca. 30.000 militærfolk udstatio- neret. I 1980 var antallet på 15.000. I 2012 var det helt nede på 7.000.

Reduktionen tog fart efter udgivelsen af den tredje franske hvidbog om nationalt forsvar og sikkerhed i 2008 (Livre blanc sur la Défense et la Securité Nationale). Den økonomiske og finansielle krise nødvendiggjorde effektivisering af forsvarsmidlerne samt refleksioner over Frankrigs primære strategiske interesser. Disse blev diagnosticeret til at befinde sig i en 'krisebue' fra Mauritanien over Sahel - og til Pakistan. Frankrig skulle ifølge hvidbogen især koncentrere sig om kriser i Sahel og i Maghreb (Nordafrika). Effektiviseringen skulle ikke underminere fransk militær tilstedeværelse i Afrika, men den skulle koncentreres i få permanente baser og i militære støttepunkter, der skulle sikre hurtig intervention i tilfælde af alvorlige kriser.

Frankrig har fire permanente baser i Gabon, Senegal, Djibouti og på øen La Réunion. Desuden har det spredt militære støttepunkter i Elfenbenskysten, Tchad, Burkina Faso, Mauritanien, Niger, Centralafrika og Guinea-golfen. Tchad har været det land, som Frankrig mere eller mindre diskret har interveneret mest $i$. Frankrig har en militærteknisk samarbejdsaftale med Tchad, men ikke en forsvarsaftale.

Samarbejdsaftalen indbefatter 'støtte uden deltagelse', hvad der er ensbetydende med uddannelse af hæren, logistisk støtte til regimet og udlevering af oplysninger om oprø- 
rere. Frankrig har fire gange støttet regimet militært imod interne oprør og libyske angreb mod Tchad. Siden 1986 har den franske militære operation 'Spurvehøg' været udstationeret i Tchad. Operation 'Spurvehøg' kaldes stadig en operation til trods for, at den er permanent udstationeret i Tchad. Operationen har bl.a. en flybase med Mirage jagerfly, som nu er blevet indsat i Mali. Som tak for fransk hjælp til regimet har Tchad sendt 1800 soldater ind i det nordlige Mali, hvor de har gjort 'det beskidte arbejde' og lidt store tab.

\section{Specialstyrker mod terrorisme}

Frankrig har indgået en aftale med Nigers regering om udstationering af franske tropper til den fælles kamp mod terrorister. I Burkina Faso har Frankrig siden 2010 meget diskret udstationeret specialstyrker i kampen mod terrorismen. Denne specialstyrke (Commandement des opérations spéciales) består af ca. 3000 mand, som i årenes løb er blevet indsat rundt omkring i Afrika, senest i Libyen og Mali.

Frankrig har ikke en decideret forsvarsaftale med Mali, men en militærteknisk samarbejdsaftale fra 1985, som handler om uddannelse af Malis hær. Der står intet om nødvendigheden af fransk militær intervention i tilfælde af interne oprør eller ekstern indblanding fra andre afrikanske lande. Frankrig kan derfor ikke bare gå ind militært i Mali. Den maliske regering skal direkte opfordre Frankrig til at intervenere, og det gjorde Mali.

Frankrig kunne intervenere så hurtigt i Mali på grund af landets militære støttepunkter, der omringer Mali. Disse faciliteter kan forholdsvist hurtigt mobilisere. De medfører også, at Frankrig har stor viden om sikkerhedspolitiske trusler i Vestafrika og Sahel.

Frankrig er tvunget til at neddrosle udstationering af landtropper i Vestafrika pga. landets skrantende økonomi. Den fjerde hvidbog om fransk forsvar og sikkerhed, som skulle have været publiceret i efteråret 2012, vil givetvis inkorporere erfaringerne fra interventionen i Mali. Læren bliver sikkert, at der skal sættes yderligere fart i europæisering og afrikanisering af militærinterventioner i Afrika samt i overvejelser over, hvorvidt Frankrig kan bevare sine hidtidige militære støttepunkter i Afrika.

\section{Et nyt 'franskafrika'?}

Afdøde præsident Mitterrand udtalte i 1980 'erne: "Der vil ikke være en fransk historie i det 21. århundrede uden båndene til Afrika”.

Lige så utænkeligt det er, at Frankrig vil opgive sin udenrigspolitiske aktivisme og sin 'mission civilisatrice', lige så utænkeligt er det, at Frankrig vil kappe båndene over til sine tidligere afrikanske kolonier. I fransk udenrigspolitisk selvforståelse er 
'Francafrique' en forlængelse og dermed en forstørrelse af Frankrig, der muliggør, at Frankrig kan spille en global rolle. Det er denne globale rolle, som Frankrig ikke vil give afkald på, selv om den koster landet dyrt økonomisk samt udsætter Frankrig for at være 'Afrikas gendarm'.

I 1960 blev de vestafrikanske stater formelt uafhængige. Men reelt bevarede de meget tæette forbindelser til Frankrig. Det lød fra Frankrig, at det var 'samarbejde' (coopération), der var i centrum. Og der blev samarbejdet - i den berygtede 'afrikanske celle, som var direkte underlagt præsidenten. Økonomiske, politiske, kulturelle og militære spørgsmål blev behandlet i al hemmelighed i denne 'celle', som havde tætte venskabsforbindelser med de afrikanske ledere, ligegyldigt hvor korrupte og diktatoriske, de var.

Der er utallige fransk-afrikanske skandalehistorie om vennetjenester, eksorbitante gaveudvekslinger og delvist mafiøse økonomiske transaktioner. Sarkozy opløste 'den afrikanske celle', men de personlige relationer fortsatte under Sarkozy. Det gør de givetvis også under Hollande, selv om han - lige som Sarkozy - har forsikret, at det skal være slut med hemmelighedskræmmeri og vennetjenester.

Det er vanskeligt at ændre denne 'dybdestruktur' af tætte fransk-afrikanske forbindelser mellem politikere, virksomheder og frankofone kulturpersoner. Begge parter har en interesse i, at symbiosen fortsætter, samt at disse forbindelser ikke bliver alt for tydelige for offentligheden.

Da Hollande blev præsident, indvarslede han en ny fransk Afrika-politik. På sin første rejse til Afrika i oktober 2012 erklærede han i en tale i Senegals hovedstad Dakar:

"Med Afrika vil jeg etablere et nyt grundlag. Vi opretholder vort engagement; men vor politik bør være anderledes end tidligere. Den bør være baseret på transparens i vore $\varnothing$ konomiske og handelsmæssige relationer. Vi skal være med til at implementere demokratiske regler og respektere suverænitet. For fremtiden ville der være tale om Frankrig og Afrika og et ligeværdigt partnerskab mellem Frankrig og Afrika baseret på respekt, klarhed og solidaritet".

Det var ikke tilfældigt, at Hollande holdt sin tale i Dakar. For det første er Senegal det land, som af alle vestafrikanske lande er tættest knyttet til Frankrig. For det andet ville Hollande med sin tale demonstrere, at han stod for et brud med tidligere fransk afrikapolitik - især med tidligere præsident Sarkozys politik.

Sarkozy holdt i 2007 en tale i Dakar, som i høj grad skadede Frankrigs omdømme i Afrika. Sarkozy udtalte, at "Afrikas tragedie var, at det afrikanske menneske ikke fuldt ud var trådt ind i historien og aldrig rigtigt havde taget skridtet ind $\mathrm{i}$ fremtiden og fremskridtet". Afrikanske politikere og intellektuelle rase- 
de over denne udtalelse. Den lugtede kraftigt af nedladende og essentialiserende paternalisme over for 'de vilde'. Men samtidig kritiserede han tidligere fransk afrikapolitik for at have været styret af nepotisme og personlige relationer til en korrupt elite.

Ifølge Sarkozy skulle disse 'fortidens slagger' ikke mere være kendetegnende for fransk afrikapolitik. Nu skulle demokratiseringstiltag fremmes, og der skulle ikke mere indgås hemmelige militæraftaler med diktatorer. I februar 2008 annoncerede Sarkozy derfor i Capetown i Sydafrika, at alle forsvarsaftalerne skulle genforhandles i al åbenhed, samt at den franske hær ikke mere ville intervenere i staternes indenrigspolitik.

\section{Europæisering}

Sarkozy ønskede europæisering og afrikanisering af mulige militære interventioner. Han ville gøre op med nepotisme og 'old boys' netværk. Det samme vil Hollande. Der er således ikke tale om brud men kontinuitet. Dog med den forskel, at Hollande ikke vil optræde som postkolonial faderskikkelse over for afrikanerne.

Europæisering af interventioner i Afrika har været på dagsordenen siden midten af 1990'erne. Den vigtigste årsag er, at Frankrig ønskede at være mindre synlig i Afrika efter folkemordet i Rwanda i 1994, hvor
Frankrig spillede en lidet flatterende rolle pga. sin støtte til hutuernes massakrer på tutsierne. Indflydelsen i Afrika skulle bevares; men det skulle fremmes via EU.

Meget sigende udtalte en fransk general i 2007, at "det er på europæisk niveau, at Frankrig for fremtiden skal mangedoble den magt, som er uundgåelig for at kunne handle med den nødvendige legitimitet'.

Frankrig var i front, hvad angik at mobilisere europæisk opbakning til deployering af en fredsbevarende europæisk operation ved navn Artemis i Den demokratiske Republik Congo i 2003. I 2006 blev en europæisk styrke EUFOR RD Congo indsat i samme land. Det lykkedes Frankrig at overtale Tyskland til at bidrage med en tredjedel af styrken. Frankrig tog initiativet i 2008 til en europæisk operation i Tchad i forsøget på at undgå spill-over effekt fra Dafur og fra det nordlige Niger, hvor der var store politiske konflikter. Frankrig bidrog med det største antal soldater i de tre operationer.

Hollande fortsætter europæiseringssporet. Forsvarsminister JeanYves Le Drian udtalte således før interventionen:

"Det er ikke Frankrig, som skal hjælpe afrikanerne med at udføre operationen i Mali. Det er Europa. Vi europæere støtter de afrikanske landes operationer med uddannelse og logistik".

Frankrig har forsøgt at smelte franske og europæiske sikkerheds- 
opfattelser sammen. Det er på det retoriske plan lykkedes, men europæiseringssporet er ret tyndt. Nogle EU-stater har stillet transportfly til rådighed - som Danmark og Storbritannien. Andre yder økonomisk støtte, og EU sender en mission af militærtrænere af Malis hær. Men det er slet ikke den militære og økonomiske hjælp, Frankrig havde regnet med.

\section{Uhyre dyrt for Frankrig}

Interventionen koster Frankrig dyrt. Det franske forsvarsministerium har beregnet, at udgifterne er på 2,7 mio. euro dagligt, hvor interventionerne i Afghanistan og Libyen dagligt kostede henholdsvis 1,4 mio. og 1,6 mio. Mali-interventionen er den dyreste, fordi hele viften af militært isenkram er indsat. Jagerfly, bombefly, kamphelikoptere, transportfly og transportskibe er i brug, og 4.000 franske soldater og militærtrænere er udstationeret. Frankrig kan simpelthen ikke økonomisk holde til, at interventionen bliver langvarig.

Frankrig gik unilateralt ind i Mali med henvisning til FN-pagtens artikel 51: "Intet i nærværende pagt skal indskrænke den naturlige ret til individuelt eller kollektivt selvforsvar i tilfælde af et væbnet angreb mod et medlem af de Forenede Nationer, indtil sikkerhedsrådet har truffet de nødvendige forholdsregler til opretholdelse af mellemfolkelig fred og sikkerhed. Forholdsreg- ler(ne) - skal uophørligt indberettes til sikkerhedsrådet”.

Lige siden præsident Hollandes præsidentindsættelse den 15. maj 2012 stod Mali og Sahel-området højt på fransk sikkerhedspolitisk dagsorden. Ifølge Hollande kunne især Europa ikke være passiv over for den terror, som 'spredte sig kun $200 \mathrm{~km}$ fra det sydlige Middelhavskyst'. I den udtalelse bliver Sahelområdet trukket tæt ind på Europas grænser. Sahel bliver til en forlængelse af Nordafrika, som opfattes som en del af Europas sikkerhedskompleks, som USA også opfatter som en potentiel sikkerhedstrussel.

Hollande kontaktede derfor USA, Storbritannien, Tyskland og Canada om situationen i Mali. Desuden inviterede han præsidenterne fra Guinea, Gabon, Senegal og formanden for afrikansk frankofoni - tidligere præsident i Senegal - til Paris for at diskutere, hvordan de stillede sig til afrikansk intervention i Mali. Ydermere telefonerede han til Tchads og Bukina Fasos præsidenter. Hollande sørgede dermed for at mobilisere det franske 'old boys' netværk i tilfælde af, at der skulle tages drastiske forholdsregler mod det nordlige Mali.

Hollande udtalte på Bastille-dagen den 14. juli 2012, at Frankrig kun ville yde logistisk og efterretningsmæssig støtte til Malis midlertidige regering, samt at det skulle være op til de afrikanske lande at bestemme, hvornår og hvordan en 
militær intervention i det nordlige Mali skulle forløbe. Hvis en intervention skulle iværksættes, skulle der først etableres en legitim regering i Mali. En sådan regering kunne opfordre andre lande til intervention inden for rammen af $\mathrm{FN}$ og Den Afrikanske Union. Samtidig erklærede ECOWAS, at de var parate til at sende en militær styrke på ca. 3.000 soldater ind i Mali. Men det skulle ske med et FN-mandat i ryggen.

På fransk initiativ og med støtte fra Marokko, Togo, Sydafrika, Indien, Tyskland og Storbritannien vedtog Sikkerhedsrådet den 12. oktober 2012 resolution 2071, som banede vejen for en afrikansk militær intervention i det nordlige Mali under forudsætning af udarbejdelse af en detaljeret plan for interventionen inden 45 dage. Resolutionen opfordrede FN-medlemsstater, ECOWAS og Den Afrikanske Union til at udarbejde et fælles interventionskoncept, som skulle munde ud i deployering af en international støtteaktion under sikkerhedsrådsmandat. Formålet med interventionen skulle være at genetablere Malis suverænitet og territoriale integritet samt at kæmpe mod den internationale terrorisme. Desuden blev Malis midlertidige regering opfordret til at begynde forhandlinger med oprørerne i det nordlige Mali.

Den 11. november 2012 holdt ECOWAS et topmøde i Nigerias hovedstad Abuja, hvor man diskutere- de omfanget af en mulig intervention, og hvem der ville deltage med landtropper. Et par dage senere publicerede Guido Westerwelle og Fabius - henholdsvis tysk og fransk udenrigsminister - en fælles udtalelse i den franske avis Le Figaro. De opfordrede EU til at støtte 'deployering af en international styrke i Mali'. FN's specielle udsending i Sahel, forhenværende statsminister og EU-præsident Romano Prodi, manede til besindelse. Ifølge Prodi kunne en sådan deployering først finde sted i september 2013.

Den 27. november 2012 modtog Hollande i Paris Malis midlertidige statsminister. Formålet med besøget var at overbevise statsministeren om nødvendigheden af udarbejdelse af en køreplan for parlaments- og præsidentvalg og dialog med det nordlige Mali. Først i januar skete det på grund af interne uenigheder blandt maliske politikere og blandt hærens officerer. Hollande satte alle sine diplomatiske kræfter ind for at få endnu en resolution igennem i sikkerhedsrådet.

Den 20. december 2012 vedtog sikkerhedsrådet enstemmigt resolution 2085, der autoriserede et års deployering af en afrikansk ledet støttemission til Mali (AFISMA) under ECOWAS, som skulle støtte den midlertidige regering i bekæmpelsen af terrorismen i det nordlige Mali. ECOWAS fik dermed bemyndigelse til at intervenere, men ikke Frankrig. 
Den 10. januar 2013 bad Frankrig om hasteindkaldelse af sikkerhedsrådet, fordi Malis regering havde 'tigget' om fransk militær hjælp. Frankrig havde derfor brug for, at FN-resolution 2085 blev benyttet hurtigere end oprindeligt planlagt. AFISMA skulle sættes hurtigt ind, således at Frankrig ikke stod alene politisk såvel som militært. I slutningen af januar var ca. 1.400 AFISMAsoldater inde i Mali samt ca. 1800 fra Tchad, som ikke er med i AFISMA.

Fra januar til april har Frankrig løbende informeret sikkerhedsrådet om sin militære indsats.

\section{FN-fredsstyrke}

Det har vist sig, at hverken AFISMA eller Malis egne styrker er i stand til at kæmpe effektivt uden fransk militær indsats. Det er derfor i fransk interesse, at FN vedtager endnu en resolution, der bemyndiger oprettelsen af en FN-fredsbevarende styrke, der kan tage over, når Frankrig gradvist trækker sig ud af Mali fra slutningen af april 2013. Frankrig har annonceret, at inden juli 2013 vil den franske styrke være halveret til 2.000. Omkring nytår 2014 vil den igen blive halveret.

En FN-rapport fra slutningen af marts 2013 foreslår, at AFISMA integreres i en FN-fredsbevarende styrke, som kan komme op på 11.200 plus 1.440 politifolk. Rapporten foreslår desuden, at der oprettes en 'parallel styrke', der skal gå målrettet mod terroristerne. Denne styrke får ikke et FN-mandat; men den skal samarbejde med den fredsbevarende styrke. Den er dermed indirekte underlagt mandatet.

For Frankrig har oprettelsen af en fredsbevarende styrke den fordel, at Frankrig undgår at fremstå som den postkoloniale militære magt. Men hvad nu, hvis forslaget om en 'parallel styrke' bliver til virkelighed? Franske soldater vil givetvis udgøre en stor del af denne styrke pga. deres kendskab til terrænet.

\section{Uklar exitstrategi}

I hele efteråret 2012 udtalte Hollande, at hvis det kom til militær intervention, ville den ikke involvere 'boots on the ground'. Under alle omstændigheder ville interventionen kun vare nogle uger. Frankrig ville ikke være i første linje. ECOWAS skulle være i front og Frankrig ville yde logistisk støtte.

Disse betingelser for en intervention holdt ikke vand. 'Støvlerne' kom straks ned på Malis jord. Efter nogle dage i Mali erklærede Hollande og forsvarsministeren, at Frankrig ville blive så længe i Malis, som det var nødvendigt og, at Frankrig ikke ville forlade Mali, før alle terrorceller var udryddet.

Samtidig udtalte udenrigsminister Fabius, at Frankrig ikke kunne blive i al evighed i Mali. Han blev hurtigt indirekte modsagt af Hollande, der 
udtalte, at Frankrig først ville forlade Mali, når der var etableret sikkerhed og en legitim autoritet i Mali, som ville være i stand til at sætte en demokratisk valgproces på skinner.

Det er økonomisk og politisk umuligt at forblive i Mali i lang tid. Men det vil også være et politisk nederlag, hvis de franske styrker forlader Mali i en tilstand af kaos i nord. Hvis det bliver tilfældet, vil alle de involverede parter - det være sig de afrikanske, europæiske samt FN anklage Frankrig for at have ført alle ud i en uovervejet intervention uden exitstrategi.

Den militære intervention skal følges op af en politisk proces og forsoning mellem det nordlige Mali og Bamako. Det ligger både i de franske kort og i FN-resolutionerne. Den maliske overgangsregering offentliggjorde endelig den 29. januar 2013 køreplanen for demokratiske præsident- og parlamentsvalg i juli 2013 samt en plan for dialog mellem det nordlige og det sydlige Mali. Mon ikke Frankrig har haft en finger med i udarbejdelsen af køreplanen?

Kan der overhovedet afholdes valg så tidligt, når nu der er ca. 100.000 internt fordrevne og i titusindvis er flygtet til nabolandene? Hvordan skal de registreres? Desuden er der hele spørgsmålet om tuaregernes fremtid og de flydende alliancer mellem smuglere, terrorister og forskellige stammer. Der er derfor stadig flere røster fremme, der advarer mod valg i juli. Men den franske udenrigsminister Fabius, som var på besøg i Bamako i begyndelsen af april, fastholder, at der skal afholdes valg i juli - og det til trods for at islamistiske terrorister igen har slået til i Timbuktu og Gao i det nordlige Mali.

Formålet med interventionen var at komme terroren til livs. Derefter blev dette formål koblet sammen med Frankrigs, EU's og FN's opfordring til at holde valg. Men terroren vil ikke være udraderet, når Frankrig begynder at trække sig, og det er svært tænkeligt at valgene i juli kan blive fair og demokratiske. Læren fra Libyen - og fra mange andre lande er - at valg ikke er en garanti for sikkerhed og legitimitet. De kan endog udløse endnu mere kaos som i Libyen.

Frankrig gik militært ind uden at miste legitimitet. Kan det gå ud uden at miste legitimitet, hvis valgene forårsager kaos? Mon ikke valgene bliver udskudt - meget mod Frankrigs vilje?

Ulla Holm er seniorforsker emeritus. 